\title{
PERANCANGAN SISTEM INFORMASI PENYEWAAN LAPANGAN PADA GOR POPEYE JAKARTA TIMUR BERBASIS JAVA
}

\author{
Kartika Titik Cahyani ${ }^{1}$, Yossi Indrawati Syuhardi ${ }^{2}$, Yuli Haryanto ${ }^{3}$ \\ 1,2,3 Informatika, Fakultas Ilmu Komputer, Universitas Indraprasta PGRI \\ Jalan Raya Tengah, Gedong, Pasar Rebo, Jakarta Timur \\ ㅌkartikatitikcahyani@gmail.com, ${ }^{2}$ yossiindrawatisyuhardi@gmail.com, 3 haryanto_yuli@yahoo.co.id
}

\begin{abstract}
ABSTRAK
Permasalahan yang terdapat pada Gor Popeye adalah proses sewanya yang masih dicatat dalam buku besar, sering terjadi kesalahan memasukkan data dan data mudah dimanipulasi oleh penjaga lapangan. Masalah tersebut memerlukan banyak waktu dan kerugian terhadap pemilik karena salah memasukkan data sewa dan manipulasi data sehingga cara ini kurang efektif dan efisien. Tujuan merancang suatu sistem informasi penyewaan lapangan ini adalah untuk memudahkan admin dalam proses menyewakan lapangan dan mengurangi kesalahan memasukkan data serta manipulasi data. Dengan menggunakan metode pengembangan sistem yaitu Waterfall dalam penelitian ini adalah dengan tahapan-tahapan seperti analisa kebutuhan, desain, implementasi, pengujian sistem, evaluasi sistem, dan pemeliharaan. Hasil akhir dari penelitian ini adalah menciptakan suatu aplikasi sistem informasi penyewaan lapangan secara terkomputerisasi yang dapat membantu pekerjaan admin dalam melakukan penyewaan lapangan dan membuat laporan yang tersimpan dengan baik serta memberikan hasil dengan cepat dan akurat.
\end{abstract}

Kata Kunci: Sistem Informasi, Lapangan, Penyewaan, Java

\begin{abstract}
The problem with Gor Popeye is that the rental process is still recorded in the ledger, there are often errors in entering data and the data is easily manipulated by field guards. This problem requires a lot of time and losses to the owner due to incorrectly entering rental data and data manipulation so that this method is less effective and efficient. The purpose of designing a field rental information system is to facilitate the admin in the process of renting out the field and reduce errors in entering data and data manipulation. By using the system development method, namely Waterfall, in this study, the stages such as needs analysis, design, implementation, system testing, system evaluation, and maintenance are used. The final result of this research is to create a computerized field rental information system application that can help admin work in conducting field rentals and making reports that are stored properly and provide results quickly and accurately.
\end{abstract}

Key Word: Information System, Field, Rental, Java

\section{PENDAHULUAN}

Pada perkembangan teknologi seperti sekarang ini banyak pemilik usaha yang sudah memanfaatkan segala teknologi. Penggunaan teknologi komputer dengan sistem yang sudah terkomputerisasi dan terintegrasi dalam suatu instansi atau organisasi pada saat ini merupakan suatu kebutuhan yang utama untuk dapat mengoptimalkan penggunaan sumber daya yang dimiliki oleh sebuah instansi maupun perusahaan.

Penggunaan komputer dalam dunia usaha mutlak diperlukan pada instansi atau perusahaan besar atau sedang berkembang, untuk memperoleh hasil yang maksimal. Dalam bidang penyewaan misalnya, sistem dan peralatan yang digunakan akan sangat mempengaruhi pelayanan terhadap pelanggan.
Masalah yang terjadi pada gor popeye yang membuat penulis ingin membuat suatu program tentang penyewaan diantaranya Proses sewanya yang masih menggunakan sistem catat dalam buku besar yang memakan waktu lama dan dapat dimanipulasi. Tingginya human error (kesalahan manusia) dalam proses pencatatan. Adanya keterlambatan dalam proses laporan penyewaan karena owner harus menunggu pekerjanya melakukan pencatatan laporan pemakaian lapangan, dan transaksi sewa lapangan. Pengolahan yang baik terhadap transaksi penyewaan akan memudahkan manajemen untuk memperoleh informasi yang up to date sehingga dapat mengambil keputusan secara tepat untuk bisa lebih berkembang. Semakin besar perusahaan tersebut, maka data yang diolah pun semakin banyak. 
Data-data tersebut harus diolah secara cepat, tepat dan akurat ditambah dengan ketelitian dan keamanan yang lebih terjamin. Berdasarkan permasalahan diatas penulis mengambil judul: "Perancangan Sistem Informasi Penyewaan Lapangan pada Gor Popeye Jakarta Timur Berbasis Java"

Perancangan adalah suatu proses yang bertujuan untuk menganalisis, menilai, memperbaiki dan menyusun suatu sistem, baik sistem fisik maupun non-fisik yang optimum untuk waktu yang akan datang dengan memanfaatkan informasi yang ada (Nur and Suyuti 2018).

(Fathansyah, 2012) menyatakan bahwa Sistem ialah sebuah keterpaduan atau tatanan yang terdiri dari beberapa komponen fungsional (dengan satuan tugas atau fungsi khusus) dan saling berhubungan secara bersama-sama yang mempunyai tujuan untuk memenuhi suatu pekerjaan atau proses tertentu. Sedangkan (Susanto, 2013) menyatakan bahwa Sistem adalah kumpulan/group dari sub sistem/komponen apa saja baik fisik maupun non fisik yang saling berhubungan satu dengan yang lain dan saling bekerja sama secara terpadu untuk mencapai tujuan tertentu.

(Yakub, 2012) menyatakan bahwa Perancangan Sistem didefinisikan sebagai perencanaan, pembuatan dan penggambaran sketsa ataupun pengaturan beberapa elemen yang terpisah menjadi kesatuan yang berfungsi secara utuh.

Sistem informasi adalah merupakan kombinasi dari teknologi informasi dan aktivitas orang yang menggunakan teknologi untuk mendukung operasi dan manajemen (Hidayat, 2018).

Bagi Gor Popeye pembuatan sistem informasi penyewaan dapat memudahkan penyajian data transaksi penyewaan lapangan secara tepat dan akurat serta pengolahan data yang terorganisir secara keseluruhan dan dapat di update secara berkala. Sedangkan pada Sistem Keamanan Data dapat mengamankan data secara menyeluruh agar terhindar dari penyalahgunaan data sehingga data yang diberikan tepat pada sasaran.
Suatu sistem yang baik harus mempunyai tujuan dan sasaran yang tepat karena hal ini akan sangat menentukan dalam mendefinisikan masukan yang dibutuhkan sistem dan juga keluaran yang dihasilkan. Sistem juga merupakan kumpulan elemenelemen yang saling terkait dan bekerja sama untuk memproses masukan (input) yang ditujukan kepada sistem tersebut dan mengolah masukan tersebut sampai menghasilkan keluaran (output) yang diinginkan.

Penyewaan adalah persetujuan untuk pemakaian sementara baik bergerak maupun tidak bergerak, dengan pembayaran suatu harga tertentu (Salim 2015).

\section{METODE PENELITIAN}

Tempat Penelitian dilakukan pada GOR Popeye yang beralamatkan di Jl. Kav. Artha Kencana No. 138 Cilangkap, Cipayung, Jakarta Timur 13870.

Desain yang digunakan dalam penelitian ini yaitu metode air terjun atau yang sering disebut metode waterfall. Metode ini sering diberi nama siklus hidup klasik, dimana dalam hal ini menggambarkan suatu pendekatan yang berurutan dan juga sistematis pada pengembangan perangkat lunak, dimulai dari kebutuhan spesifikasi si pengguna lalu berlanjut melalui suatu tahapan-tahapan perencanaan (planning), permodelan (modeling), konstruksi (construction), serta penmberian sistem kepada pengguna (deployment), diakhiri dengan memberikan dukungan pada perangkat lunak yang dihasilkan secara lengkap (Pressman 2012).

Dalam pengumpulan data untuk penelitian antara lain:

Studi Kepustakaan, Data dan informasi dikumpulkan dari kutipan-kutipan buku-buku, artikel jurnal, hasil laporan dan bahan lainnya yang berkaitan dengan penelitian ini. Dari bahan-bahan tersebut kemudian diambil teoriteori yang dapat dijadikan suatu landasan untuk menganalisa masalah yang terjadi didalam penelitian.

Studi Lapangan, Pada Studi lapangan, penulis melihat langsung sistem penilaian kinerja pegawai yang menggunakan sistem manual (mencatat dengan tangan). Dalam 
studi lapangan penulis menggunakan teknik pengumpulan data antara lain dengan cara:

Wawancara yaitu teknik pengumpulan data dengan bertanya langsung kepada pemilik GOR Popeye yang mengerti dan paham mengenai proses penyewaan lapangan. Metode wawancara merupakan metode yang sangat efektif dalam pengumpulan data.

Dari hasil wawancara tersebut penulis menyimpulkan bahwa membutuhkan waktu untuk melakukan pencatatan dan membuat laporan tersebut. Hal ini diakibatkan oleh sistem pencatatan yang masih manual dalam penyewaan lapangan berupa buku besar dimana harus mencatat waktu bermain, nama penyewa dan pembuatan laporan. Harapan beliau kedepannya sistem yang berjalan sudah terkomputerisasi sehinga mempunyai sistem penyewaan lapangan yang baik dan sistem dapat membuat laporan yang lebih efektif dan juga efisien.

Observasi adalah melakukan pengamatan dan pencatatan secara sistematik kepada unsurunsur yang muncul dalam suatu gejala dalam bentuk objek penelitian. Mendefinisikan observasi untuk memilih, mengubah dan juga pengodean serangkaian perilaku dalam ssasana sesuai dengan tujuan empiris (Hikmat 2011). Penulis melakukan observasi awal untuk mengumpulkan data-data yang dibutuhkan untuk analisa proses penyewaan lapangan mulai bulan April.

\section{Langkah Pengembahangan Sistem}

Pada tahapan analisis dan definisi kebutuhan penyewaan lapangan penulis melakukan pengamatan terhadap sistem yang sedang berjalan dan konsultasi dengan pemilik GOR Popeye mengenai masalah yang terjadi. Pada tahapan desain sistem dan perangkat lunak penyewaan lapangan dibentuk rancangan berdasarkan persyaratan yang diinginkan oleh pemilik. Pada tahapan implementasi dan pengujian, hasil dari desain perangkat lunak direalisasikan sehingga program-program membentuk satu set program dan diuji sesuai dengan kebutuhan penyewaan lapangan.

Pada tahapan integrasi dan pengujian sistem dilakukan untuk memastikan apakah semua fungsi sistem bekerja dengan baik dan mencari apakah masih ada kesalahan pada sistem. Pada tahap terakhir yaitu implementasi sistem dan pemeliharaan terdiri dari koreksi dari berbagai kesalahan yang tidak ditemukan di tahap-tahap sebelumnya, perbaikan atas implementasi dan pengembangan unit sistem, serta pemeliharaan program.

\section{HASIL DAN PEMBAHASAN \\ Analisa Permasalahan}

Berdasarkan hasil analisa dan uraian umum tentang masalah-masalah yang dihadapi tersebut, maka alternatif dalam proses penyewaan lapangan adalah membuat aplikasi sistem penyewaan lapangan yang terkomputerisasi sehingga dapat dihasilkan informasi yang tepat, cepat dan akurat, data hasil penyewaan bisa disimpan di hard disk sehingga dapat mengurangi pemakaian kertas, membuat aplikasi yang mudah digunakan dan dimengerti oleh admin penjaga lapangan. Berikut adalah gambaran sistem yang diusulkan oleh penulis untuk GOR Popeye di cipayung.

Penulis menggunakan Diagram Alir Data (DAD) untuk merancang sistem informasi penyewaan lapangan GOR Popeye di cipayung. Diagram Alir Data (DAD) adalah representasi grafik yang menggambarkan aliran informasi dan transformasi informasi yang diaplikasikan sebagai data yang mengatur dari masukan (input) dan keluaran (output). DFD tidak sesuai untuk memodelkan sistem yang menggunakan pemrograman berorientasi objek (Sukamto, Aryani, and Shalahuddin 2013).

Menurut Ladjamudin (2013) "Diagram Alir Data merupakan model dari sistem untuk menggambarkan pembagian sistem ke modul yang lebih besar".

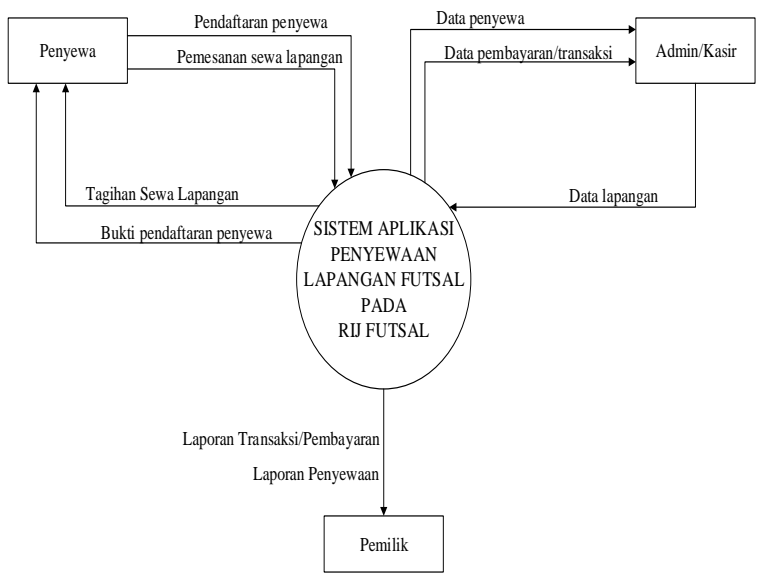

Gambar 1. Diagram Konteks yang Diusulkan 


\section{Entity Relationship Diagram (ERD)}

ERD adalah suatu diagram untuk menggambarkan desain konseptual dari model konseptual suatu basis data relasional. ERD juga merupakan gambaran yang merelasikan antar objek yang satu dengan objek yang lain dari objek di dunia nyata yang sering dikenal dengan hubungan antar entitas (Yanto 2016).

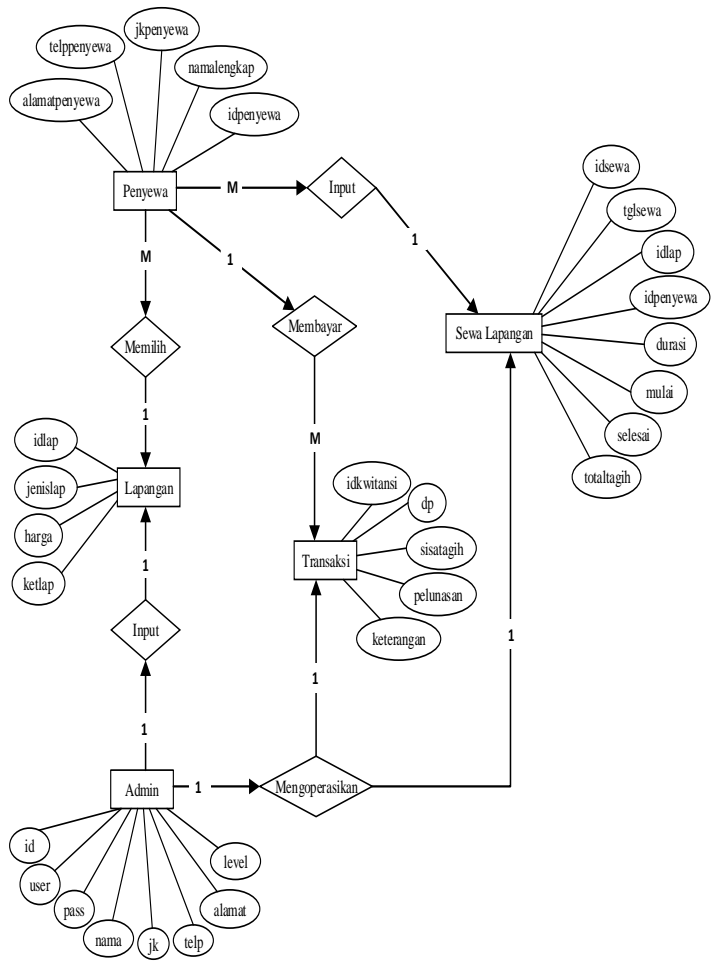

Gambar 2. ERD (Entity Relationship Diagram)

Berikut adalah tampilan layar dan hasil pengujian pada software program yang telah di buat dengan bahasa pemrograman Java.

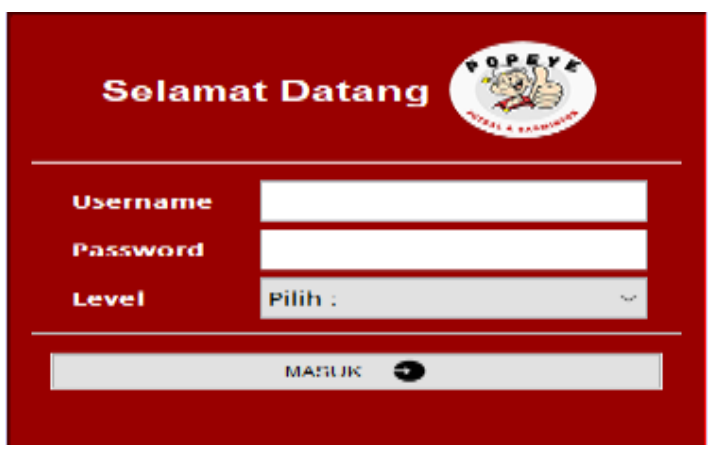

Gambar 3. Form Login

Menu login digunakan sebagai kata kunci sebelum admin/petugas memasuki program utama. Menu ini bertujuan untuk mengamankan program supaya tidak dapat diakses oleh orang lain kecuali admin/petugas.

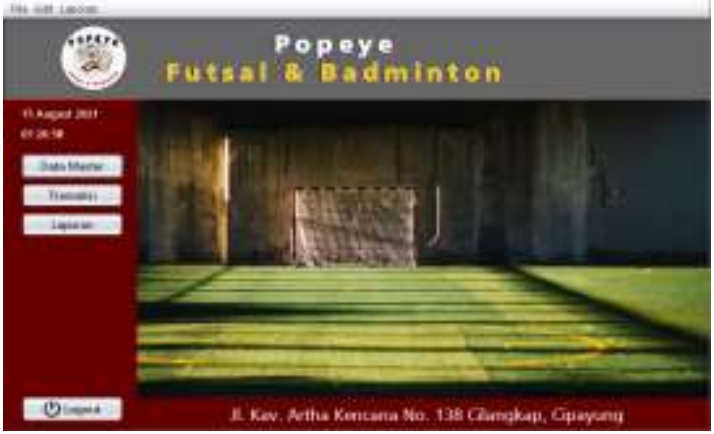

Gambar 4. Form Menu Utama

Menu diatas menampilkan tampilan menu utama sistem informasi penyeawaan lapangan. Tombol menu ini berfungsi untuk memasukkan data-data yang berkaitan dengan Data Admin, Data Penyewa, Data Lapanga, Sewa Lapangan, Pembayaran Sewa, Dan Laporan seluruh data yang ada.

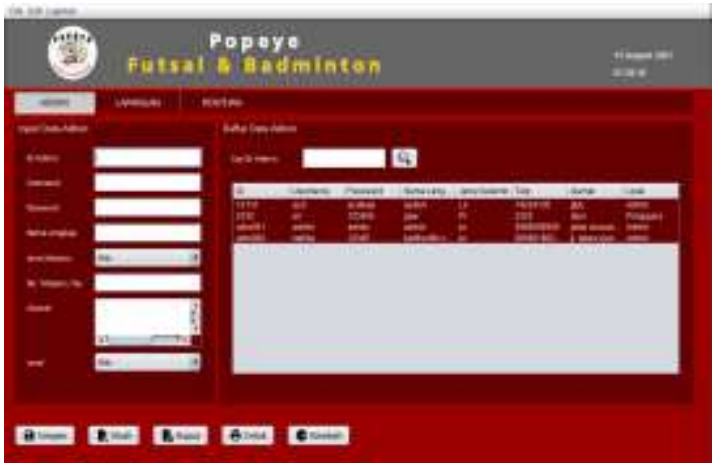

Gambar 5. Form Data Admin

Layar di atas menampilkan tampilan form data admin. Pada layar form data admin untuk meng-input data admin/petugas yang terdiri dari Id Admin, Username, Password, Nama Lengkap, Jenis Kelamin, No. Telpon/HP, Alamat, dan Level Pengguna.

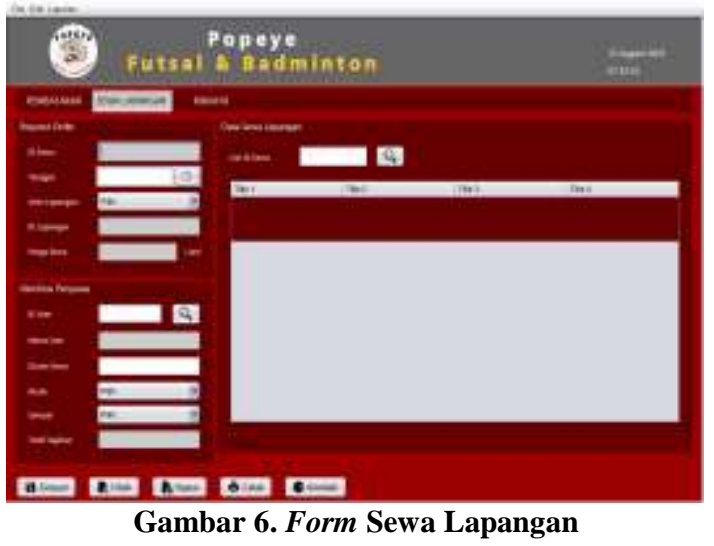

Layar di atas menampilkan tampilan form sewa lapangan. Pada layar form sewa lapangan untuk meng-input data permintaan 
sewa lapangan yang terdiri dari Id Sewa, Tanggal, Jenis Lapangan, Id Lapangan, Harga Sewa, Id User, Nama User, Durasi Sewa, Jam Mulai, Jam Selesai, dan Total Tagihan.

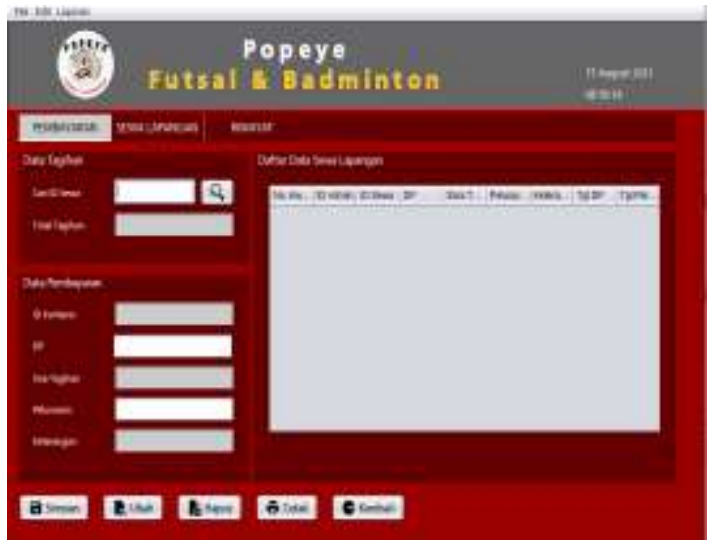

Gambar 7. Form Pembayaran

Layar di atas menampilkan tampilan form Pembayaran. Pada layar form Pembayaran untuk meng-input data Pembayaran sewa lapangan yang terdiri dari kolom cari Id Sewa, dan total tagihan, ID Kwitansi, memasukkan jumlah DP yang dibayarkan oleh penyewa, kolom sisa tagihan untuk melihat jumlah sisa pembayaran yang akan dibayarkan selanjutnya, kolom pelunasan untuk memasukkan jumlah dari sisa pelunasan yang harus dibayarkan setelah menggunakan lapangan, dan kolom keterangan yang ada akan menunjukkan keterangan bayar.
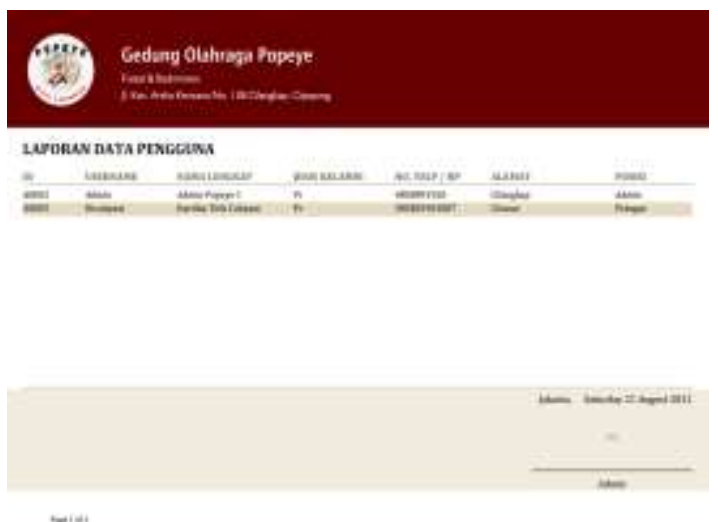

Gambar 8. Laporan Data Admin

Layar di atas menampilkan tampilan laporan data admin. Pada layar laporan data admin untuk mengecek data admin/petugas yang terdiri dari Id Admin, Username, Nama Lengkap, Jenis Kelamin, No. Telpon/HP, Alamat, dan Posisi / Level.
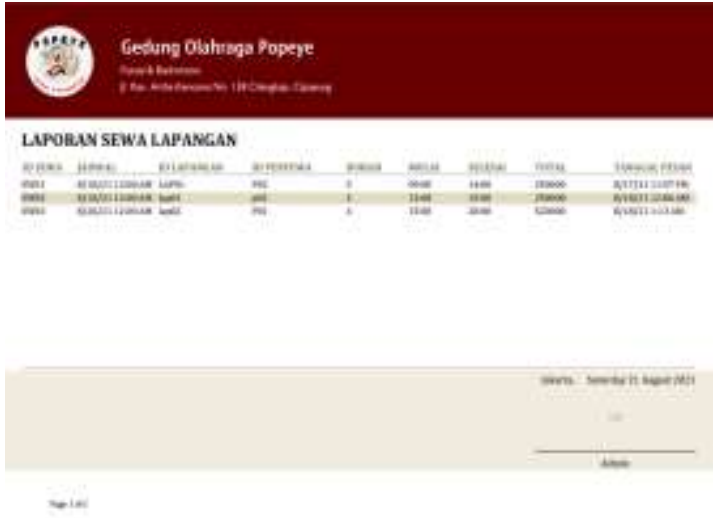

Gambar 9. Laporan Sewa Lapangan

Layar di atas menampilkan tampilan laporan data sewa lapangan. Pada layar laporan data sewa lapangan untuk meng-input data permintaan sewa lapangan yang terdiri dari Id Sewa, Tanggal, Jenis Lapangan, Id Lapangan, Harga Sewa, Id User, Nama User, Durasi Sewa, Jam Mulai, Jam Selesai, dan Total Tagihan.
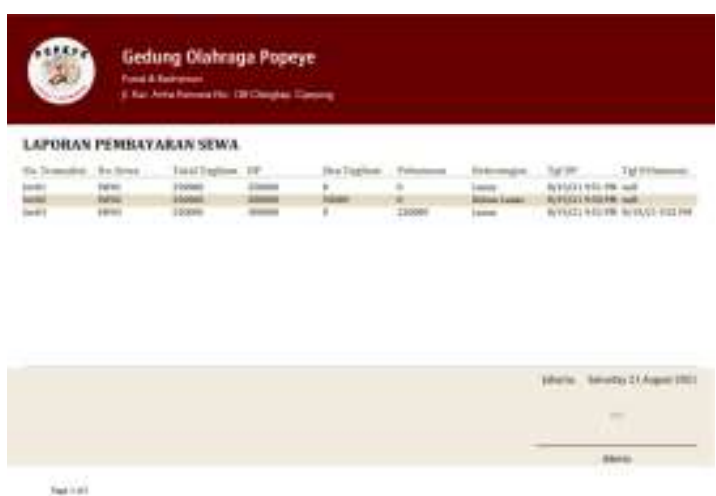

Gambar 10. Laporan Pembayaran

Layar di atas menampilkan tampilan laporan data pembayaran. Pada layar laporan data Pembayaran untuk mengecek data Pembayaran sewa lapangan yang terdiri dari No. Transaksi, No. Sewa, total tagihan, DP, sisa tagihan, pelunasan, keterangan, tanggal pembayaran $\mathrm{Dp}$, dan tanggal pembayaran Pelunasan.

\section{SIMPULAN DAN SARAN}

Berdasarkan hasil penelitian yang dilaksanakan, maka dapat disimpulkan beberapa hal mengenai sistem informasi penyewaan lapangan pada GOR Popeye Jakarta timur adalah :

1. Perancangan sistem informasi penyewaan lapangan ini dirancang sebagai solusi bagi pihak GOR Popeye dalam mengelola dan pembuatan laporan penyewaan lapangan 
secara cepat, tepat dan akurat dibanding secara manual.

2. Dengan adanya aplikasi penyewaan ini, kinerja admin dalam bertugas dapat lebih efisien, efektif dan maksimal di dalam pengolahan data di Gor Popeye.

3. Dengan adanya sistem informasi penyewaan ini, dapat menangkal kemungkinan adanya manipulasi data, karena sudah terkomputerisasi sehingga dapat dipantau pemilik secara berkala.

4. Dengan adanya sistem informasi penyewaan ini, penyimpanan data-data penyewaan lapangan dapat terorganisir dengan baik.

Dalam pembuatan Sistem Informasi Penyewaan Lapangan pada Gor Popeye ini masih banyak hal yang dapat dikembangkan, agar penerapan sistem yang diusulkan ini dapat terwujud sesuai dengan harapan, maka penulis memberikan beberapa saran yang sebaiknya perlu diperhatikan : sebelum sistem baru dilaksanakan, sebaiknya Admin penjaga lapangan harus diberikan penjelasan sebaikbaiknya terlebih dahulu mengenai proses kerja sistem yang akan di terapkan, sehingga tidak terjadi kekeliruan dan kecanggungan dalam menggunakan aplikasi baru tersebut serta perlu dilakukan pelatihan penggunaan sistem tersebut agar mereka dapat mengetahui dan memahami cara kerja sistem yang baru. Keamanan sistem harus dijaga dengan cara memberikan kepercayaan pada personil yang bisa bertanggung jawab. Meskipun sistem sudah terkomputerisasi, ketelitian dalam memasukkan data perlu diperhatikan agar data yang sudah disimpan benar-benar merupakan salinan dari data sumber. Sistem ini diharapkan dapat dikembangkan dan dimanfaatkan sebagaimana mestinya tanpa adanya penyalahgunaan pada informasi yang diberikan.

Penulis menyadari bahwa masih banyaknya kekurangan dalam pembuatan Aplikasi sistem informasi penyewaan lapangan pada GOR Popeye di Jakarta Timur. Maka dari itu, penulis berharap sistem ini dapat dikembangkan lebih baik lagi dan mendapatkan saran yang lebih baik lagi.

\section{DAFTAR PUSTAKA}

Fathansyah. 2012. Basis Data Edisi Revisi. Informatika.

Hidayat, Rohmat. 2018. Konsep Sistem Informasi Dan Implementasi. Jakarta: Deepublish.

Hikmat, Mahi M. 2011. "Metedologi Penelitian Dalam Perspektif Ilmu Komunikasi Dan Sastra." : 73.

Ladjamudin, Al - Bahra. 2013. Analisis Dan Desain Sistem Informasi. Graha Ilmu.

Nur, Rusdi, and Muhammad Arsyad Suyuti. 2018. Perancangan Mesin-Mesin Industri. Yogyakarta: Deepublish.

Pressman, Roger S., Ph.D. 2012. Rekayasa Perangkat Lunak Pendekatan Praktisi. Yogyakarta: ANDI.

Salim. 2015. Pengelolaan Sistem Penyewaan. Jakarta: Deepublish.

Sukamto, Rosa Aryani, and M. Shalahuddin. 2013. Rekayasa Perangkat Lunak Terstruktur Dan Berorientasi Objek. Bandung: Informatika.

Susanto, Azhar. 2013. Sistem Informasi Akuntansi. Bandung: Lingga Jaya.

Yakub. 2012. Pengantar Sistem Informasi. Graha Ilmu.

Yanto, Robi. 2016. Manajemen Basis Data Menggunakan MySQL. Yogyakarta: Deepublish. 